\title{
A Course Initiating an Engineering Thesis ${ }^{\nabla}$
}

\author{
Pat LaCourse, Barrett Rock \\ Alfred University/University of New Hampshire
}

\section{Introduction}

Every college and university has prerequisites for entrance into its engineering graduate programs. Academic background is examined via transcript, GRE (Graduate Record Exam) scores, and for non-native applicants, TOEFL (Test of English as a Foreign Language) scores. Personal statements, references and interviews attempt to address personality traits and skills: motivation, perseverance, enthusiasm, organization, independent thinking, problem solving, time management, etc. Upon review of the criteria, the committee decides whether the student is a candidate for success.

The screening process is not fail-safe, however. Those who enter a program without the requisites or falter in the program need help in order to reach degree completion. When there is trouble meeting course work or qualifying examination standards, tutors may be provided. If financial barriers are high, grants may be sought. If research results are too discouraging, communication and support from an advisor can improve perspective (advisor supervision was thought to be a significant factor in student retention in the ' $70 \mathrm{~s}$ and ' $80 \mathrm{~s}^{2}$ ). Other reasons for students leaving a program (time requirements too intense, failing to submit the thesis, personal problems, etc.) may be ameliorated by the course proposed here. In 1998 a Graduate Student Services Survey was conducted to gather information for increasing satisfaction and retention. ${ }^{3}$ More than a third of the respondents were interested in more information on resources and writing theses.

Lack of preparation increases stress when tackling any task and is a major failure factor. There has been much discussion about the technical writing abilities of engineers. Spretnak ${ }^{4}$ postulates that people are drawn to engineering because they believe there will be less writing, but the engineer's writing skills are vital. The Society of Manufacturing Engineers ${ }^{5}$ and employers express concern with evidence of low communication skills. Surveys indicate proficiency in communication may be a deciding factor in an engineer's successful career, ${ }^{4}$ ABET insists each graduate should demonstrate "both mastery of the subject matter and a high level of communication skills", ${ }^{6}$ yet surveys over an eight year span showed little change in writing requirements in engineering curriculums. ${ }^{7,8}$ Most curriculums require undergraduate Freshman Composition while recommending another course in communications and/or technical writing. This may not be adequate for a task with the magnitude and complexity of a thesis. Since technical content demands much of the curriculum, programs search for ways to integrate writing and speaking skills. Two such programs, Writing Across the Curriculum (WAC) and

${ }^{\nabla}$ In the United States the term dissertation generally refers to the paper written to obtain a doctorate, and thesis most often describes the Masters document. In Britain it is just the opposite. ${ }^{1}$ In other countries they may use thesis to describe either. 'Thesis' will be used here to refer to a Ph.D. or M.S. work.

Proceedings of the 2002 American Society for Engineering Education Annual Conference \& Exposition Copyright (C) 2002, American Society for Engineering Education 
Writing to Learn (WTL), emphasize discipline-specific writing. The course outlined below follows some of their guidelines.

Often the thesis presents even more difficulty for the international student, a considerable segment of the graduate engineering population. A 2000 National Science Foundation study reported that $52 \%$ of engineering doctorates were earned by international students. ${ }^{9}$ It is even more of a cultural assimilation for those from Asia (more than half of the total foreign students in $\left.1999^{10}\right)$. When English is a second language, the disadvantage is not just in vocabulary, but in style, expectations, experiences, perspectives, etc. When students are insecure about their writing ability, they approach the task under added stress. The written results of many months of labor are meant to reflect positively on both graduate and sponsoring institution. Even if the student obtains his or her degree, a poorly written thesis can shield the glow of excellent research. This paper describes a mandatory, introductory seminar that would improve the final product, decrease the total time from entry to defense, and reduce stress.

\section{Background}

Proposals for improving graduate writing have focused on writing centers or workshops. ${ }^{11}$ These meet with varying degrees of success. Allison et al. ${ }^{11}$ note that most workshops dispense writing tasks that are short, structured, disassociated from thesis material, and little different than writing assignments in content areas. Evaluations of workshops devoted to thesis writing for non-U.S. students ${ }^{12,13}$ indicate that students thought organizing and editing skills would be most useful early in their degree program, but they had difficulty finding time in their busy schedules.

Adding a writing course is not the answer, because it further burdens a packed curriculum and concepts learned do not necessarily transfer to the thesis task. Steinker describes a course for the preparation of a thesis. ${ }^{14}$ He laments the lack of readiness in research and writing skills of the average student. His course, however, was provided prior to rather than in conjunction with the actual thesis project.

Most students have no idea of the effort that a thesis demands. Many tend to begin the writing stage when research is almost finished. Although this was understandable before word processing programs, it is no longer necessary or advisable. It's estimated that the writing process (including revisions) takes one third of the total time allocated to obtaining the degree. ${ }^{15}$ If writing is left until the end, would-be graduates are faced with the overwhelming task of analyzing and synthesizing literature and research data, and organizing all into a clear and coherent package. They also chance missing vital information if their literature search is rushed. Although stipulating the need for initiating the graduate into the thesis process early, a similar course should be offered in curriculum with an undergraduate thesis requirement.

\section{Course/Seminar}

New graduate students need orientation to program demands and expectations; workings of laboratories, libraries and other campus facilities; appropriate contact persons; and effective methods for obtaining materials and information just as Freshmen do, albeit their needs are not as extensive. Orientation may be separate or included in a seminar course that also gathers degree candidates for discussion of research topics. Such a course could be augmented to include thesis preparation. While a one-credit course or no-credit seminar would be adequate, a 
three-credit course would be comprehensive. Responsibility for the course can be an information or communications specialist, engineering professor, or team.

\section{Course Format}

Table 1 lists a sample syllabus for a one-credit course. Each week's meeting may include lecture (thesis sections, scientific method, tools, etc.), seminar (exchange of ideas), presentations, small group tasks and/or writing lab. Students use a logbook, same as or similar to the logbook in the lab. This fosters the behavior of having a thesis workbook handy at all times to jot down speculations, experiences, insights, etc. as they occur. All in-class writing is expected to be in this notebook (or laptop).

Table 1. Sample Syllabus

\begin{tabular}{|c|c|c|}
\hline Week & & Assignments \\
\hline 1 & $\begin{array}{l}\text { Welcome/Introduction/ Orientation } \\
\text { Time Management }\end{array}$ & \\
\hline 2 & Scientific Method & Read Chap. 5, 6 Smith $^{\mathrm{i}}$ \\
\hline 3 & Scientific Method & Small-Group Presentations \\
\hline 4 & $\begin{array}{l}\text { Thesis Statements } \\
\text { Small groups review samples, critique theses }\end{array}$ & $\begin{array}{l}\text { Read F\&F Fii pp. 1-30, } 81-90 \\
\text { and Evans iii Chap } 6 \\
\text { Bring a thesis to class }\end{array}$ \\
\hline 5 & $\begin{array}{l}\text { Thesis Sections and Format } \\
\text { Guidelines for Editing (handouts) }\end{array}$ & $\begin{array}{l}\text { Evans Chap } 5 \\
\text { Thesis Statement due }\end{array}$ \\
\hline 6 & $\begin{array}{l}\text { Thesis Background } \\
\text { Resource Searching I - Library Catalog/WorldCat, } \\
\text { basic article databases }\end{array}$ & $\begin{array}{l}\text { F\&F pp. } 91-105 \\
\text { Evans Chap } 7\end{array}$ \\
\hline 7 & $\begin{array}{l}\text { Thesis Justification } \\
\text { Resource Searching II - advanced searching, } \\
\text { profiling/alerts }\end{array}$ & F\&F pp. $37-52$ \\
\hline 8 & $\begin{array}{l}\text { Thesis Titles } \\
\text { Edit Backgrounds }\end{array}$ & $\begin{array}{l}\text { F\&F pp. 53-61 } \\
\text { Thesis Background due }\end{array}$ \\
\hline 9 & $\begin{array}{l}\text { Writing Tools - word processing, bibliographic } \\
\text { software } \\
\text { Review Titles }\end{array}$ & $\begin{array}{l}\text { F\&F pp. } 62-80 \\
\text { Evans Chap } 4 \\
\text { Thesis Title due }\end{array}$ \\
\hline 10 & $\begin{array}{l}\text { References } \\
\text { Resource Search III - conference articles, technical } \\
\text { reports, theses }\end{array}$ & F\&F pp. 133-139 \\
\hline 11 & $\begin{array}{l}\text { Abstracts } \\
\text { Review Justifications }\end{array}$ & Thesis Justification due \\
\hline 12 & $\begin{array}{l}\text { Databases for Property Data (SciGlass, Matlab, PDF } \\
\text { File, etc.) } \\
\text { Review references }\end{array}$ & Thesis References due \\
\hline 13 & $\begin{array}{l}\text { Ethics - Copyright, Plagiarism and Integrity } \\
\text { Review Literature Review }\end{array}$ & $\begin{array}{l}\text { F\&F p 158-162 } \\
\text { Literature Review due }\end{array}$ \\
\hline 14 & Review Introductions & Thesis Introduction due \\
\hline
\end{tabular}

${ }^{i}$ Smith, R. V., Graduate Research: A Guide for Students in the Sciences ${ }^{16}$

${ }^{i i}$ F\&F -A. J. Friedland and C. L. Folt, Writing Successful Writing Proposals ${ }^{17}$

${ }^{i i i}$ Evans, D., How to Write a Better Thesis or Report ${ }^{18}$

The first task for groups is to prepare a presentation on one of the five steps of the Scientific Method. An eight-minute segment is allowed for each group presentation, defining the problem, developing a hypothesis or thesis statement, etc. In later classes, small groups are used 
to discuss theses statements and titles. For instance, after a lecture on developing thesis statements and a review of model statements, each group critiques a statement from an existing thesis.

In order to involve students in surveying literature, volunteers become familiar with different databases for demonstration in class. They comment on strengths, weakness, and searching tips for the assigned database. An information specialist is present to add input, although the demonstrator is encouraged to anticipate question s and meet with a librarian ahead of time if necessary. The same format is followed for property databases.

Attitude is very important for productivity. Competence and feelings of support breed enthusiasm and creativity. Discussions devoted to answering questions, addressing problems, and offering tips and suggestions are integral for building community. Senior degree candidates and former students are invited to an occasional session, to answer questions particular to graduate needs.

All written assignments are works toward the candidate's thesis. After the thesis statements and titles assignments, each written submission is peer reviewed. (Although a credit course is recommended, if the course is pass-fail, editing sessions provide added incentive to produce a workable item on time.) Feedback is also provided by the thesis format monitor. While fulfilling class requirements, no written assignment is considered to be a final copy. Students orally present their thesis proposals during the Spring Graduate Seminar.

\section{Text}

Although not specifically meant for thesis writing, Writing Successful Writing Proposals ${ }^{17}$ defines each of the traditional sections: title, thesis statement, objectives, significance, summary and abstract. Some parts of the book are not pertinent for this course (budget, submittal and tracking), but all should be invaluable to the future degree-holder. Many faculty list grant proposal before journal article writing in career importance. ${ }^{19}$ How to Write a Better Thesis or Report ${ }^{18}$ adds information on figures and tables, using word processors, and grammar and punctuation. Graduate Research ${ }^{16}$ reviews the principles of scientific research and the ethics of a scientist.

Paltridge ${ }^{1}$ opined that most texts on writing theses devote only small sections to the actual writing process itself, especially the organizational structure. That may be due to the peculiarities of the individual institution. In fact degree programs within the same institution might promote different types of theses. Although there are four types of theses acceptable in many degree programs, students (especially those from other countries) tended to be aware of only the traditional type. ${ }^{1}$ Specific Graduate Manuals for the particular degree program are provided.

\section{Logs}

Writing in education is generally a formal process, structured in format and defined by timelines. Although formal writing is necessary for accountability, Hawkins et al. ${ }^{20}$ advocate informal writing (read only by the writer) for learning. When freed from the tentacles of deadlines and grade-seeking, writing can deepen critical-thinking skills. Any method of making notes of summary and reflection encourage higher level cognition: metacognition, synthesis, 
analysis, and problem solving. Having reflected throughout the term, the student becomes more confident and able to produce a more sophisticated formal account. ${ }^{20}$

\section{Peer-editing}

Although recognizing its value, instructors outside of the English and Communication disciplines may consider themselves ill-trained to adequately correct grammar, organization, style, etc. 20.21 The graduate in this course is expected to have all assignments reviewed and supported by the advisor. Prior to that, however, class time is afforded for peer-editing. Peer review strengthens the skills of author and editor and facilitates the advisor's review of second drafts. ${ }^{22}$ Taking this route can be a disaster, however, without adequate training in the use of questions, suggestions and constructive comments, and the avoidance of criticism and sugarcoated praise. In addition, an editing checklist provides a guideline for the thesis author in creating the assignment.

\section{Online}

Discussions may be cut short due to time constraints in the classroom. An online classroom management software program is used to facilitate continued communication among students, and with the instructor. Blackboard (http://www.blackboard.com) is one such program, which allows email, bulletin board and real-time chat capabilities. Links are made to tutorials, Graduate Manual, handouts and web resources.

\section{Summary}

The goal of this course is to place the thesis reins into the hands of the author, and open the starting gate. The student enters the laboratory armed with the concepts of scientific research, and builds the framework of the final project with the practical tools to assure success. The course challenges, supports, and answers questions to ease the student's transition to independent researcher. The last assignment requires blending the earlier ones complete with science and technical background, literature review, thesis statement, and justification. By completing required thesis assignments early in the degree program, the candidate gains a global perspective, direction, and control. The student author is encouraged to continue the iterative drafting method throughout the research process.

\section{References}

1. Paltridge, B., "Thesis and Dissertation Writing: An Examination of Published Advice and Actual Practice," English for Specific Purposes, vol. 21, no. 1, 2002, pp. 125-143.

2. Alderman, G., 1994. "Doctor, Doctor Geoffrey Alderman Warns Against Attacks on the Research Doctorate by Skillologists and Others" UMI Proquest. Accessed on: January 12, 2002. Available at http://proquest.umi.com/pqdweb?Did=000000069462650\&Fmt=3\&Deli-1\&Mtd=1\&ldx=21\&Sid=1\&RQT=309

3. Hahs, D. L., "Creating 'Good' Graduate Students: A Model for Success," ERIC Digest, 1998, ED428040.

4. Spretnak, C. M., "A Survey of the Frequency and Importance of Technical Communication in an Engineering Career," Technical Writing Teacher, vol. 9, 1982, pp. 133-136. 
5. Society of Manufacturing Engineers, Manufactuing Education Plan: Phase I Report -Industry Identifies Competency Gaps among Newly Hired Engineering Graduates, Dearborn, MI, 1997.

6. Engineering Accreditation Commission, 2000. "Criteria for Accrediting Engineering Programs" ABET (Accreditation Board for Engineering and Technology, Inc. Accessed on: January 22, 2002. Available at http://www.abet.org/images/Criteria/eac_criteria_b.pdf

7. Loeb, H., "Writing Courses in the Engineering College Curriculum," Journal of Technical Writing and Communication, vol. 15, no. 1, 1985, pp. 43-47.

8. Kramberg-Walker, C., "The Need to Provide Writing Support for Academic Engineers," IEEE Transactions on Professional Communication, vol. 36, no. 3, 1993, pp. 130-136.

9. Hill, S. T., 2001. "Science and Engineering Doctorate Awards: 2000, NSF 02-305" National Science Foundation, Division of Science Resources Statistics, Table 4. Accessed on: January 30, 2002. Available at http://www.nsf.gov/sbe/srs/nsf02305/start.htm

10. Desruisseaux, P., "Foreign Students Continue to Flock to the U.S. Annual report finds that economic turmoil in Asia did not lead to a decrease in enrollments," The Chronicle of Higher Education, December 10, 1999, p. A57.

11. Allison, D., Cooley, L., Lewkowicz, J., \& Nunan, D., "Dissertation Writing in Action: The Development of a Dissertation Writing Support Program for ESL Graduate Research Students," English for Specific Purposes, vol. 17, no. 2 , 1998, pp. 199-217.

12. Richards, R., "Thesis-dissertation Writing for EFL Students; An ESP Course Design," English for Specific Purposes, vol. 7, 1988, pp. 171-180.

13. Paltridge, B., "Thesis and Dissertation Writing: Preparing ESL Students for Research," English for Specific Purposes, vol. 16, no. 1, 1997, pp. 61-70.

14. Steinker, D. C., "A Course in Research and Writing for Graduate Students in Geology," Journal of Geological Education, vol. 29, no. 4, 1981, pp. 180-183.

15. Davis, G. B. \& Parker, C. A., Writing the Doctoral Dissertation, Woodbury, NY: Barron's Educational Series, 1979.

16. Smith, R. V., Graduate Research: A Guide for Students in the Sciences, 3rd ed., Seattle, WA: University of Washington Press, 1998.

17. Friedland, A. J. \& Folt, C. L., Writing Successful Writing Proposals, New Haven, CT: Yale University Press, 2000 .

18. Evans, D., How to Write a Better Thesis or Report, Carlton, Victoria: Melbourne University Press, 1995.

19. Swales, J., "Utilizing the Literatures in Teaching the Research Paper," TESOL Quarterly, vol. 21, no. 1, 1987, pp. 41-68.

20. Hawkins, S., Coney, M. B., \& Bystrom, K.-E., "Incidental Writing in the Engineering Classroom," Journal of Engineering Education, vol. 85, no. 1, 1996, pp. 27-33.

21. Moss, A. \& Holder, C., Improving Student Writing: A Guidebook for Faculty in All Disciplines, Dubuque, Iowa: Kendall/Hunt Publishing, 1988.

22. Olds, B. M., "Four Effective Writing Strategies for Engineering Classes. III. Peer Editing," Journal of Engineering Education, vol. 88, no. 1, 1999, pp. 53-57.

Proceedings of the 2002 American Society for Engineering Education Annual Conference \& Exposition Copyright (C) 2002, American Society for Engineering Education 
PAT LACOURSE is the Engineering and Science Librarian at Scholes Library, New York State College of Ceramics, Alfred University. Besides developing the science and engineering collection and providing reference support, LaCourse is the format reviewer for all graduate theses in Engineering. Prior to this course effort, she has developed templates, and given classes in database search techniques and writing tools.

BARRETT ROCK is a professor in the Natural Resources Department and a Research Scientist in the Complex Systems Research Center at the University of New Hampshire. Rock has offered a graduate level 3-credit course for the last 10 years. Course requirements include a full-blown proposal, a series of three oral presentations and a research-style poster for display at a departmental poster session devoted to new graduate student projects. 